\title{
Vertalingstrategie met die oog op sinopsissamestelling1
}

H C van Zyl

(UOVS)

\section{ABSTRACT}

\section{Translation strategy with a view to synopsis construction}

Author is in the process of compiling a synopsis of the synoptic Gospels in Afrikaans. A new, literal translation is being made to serve the needs of synoptic comparison. This article deals with the translation strategy which follows. The strategy rests on two pillars: consistently rendering, as far as possible, a single Greek word by the same Afrikaans equivalent, and keeping as closely as possible to the Greek syntax. Various aspects and problems of this strategy are discussed, illustrated with numerous examples.

\section{INLEIDING}

Ek is tans besig met die samestelling van 'n sinopsis in Afrikaans van die eerste drie Evangelies. Na my mening is daar beslis behoefte aan so 'n hulpmiddel. Naas die bekende sinopsisse in Grieks ${ }^{1}$, bestaan daar ook reeds etlikes in Engels ${ }^{2}$, Duits ${ }^{3}$, Frans ${ }^{4}$ en Nederlands ${ }^{5}$. Maar om die een of ander rede het niemand dit nog nodig gevind om 'n sinopsis in Afrikaans te laat verskyn nie. Die tyd is dus nou ryp daarvoor. Dit sal vir 'n groot getal Afrikaanse studente en geestelike werkers wat nie toegang tot die grondtaal het nie 'n belangrike hulpmiddel in die akademiese studie van die sinoptiese Evangelies wees. Selfs vir studente en predikante wat wel toegang tot 'n Griekse sinopsis het, kan dit as 'n handige eerste naslaanmiddel funksioneer, waarna die Grieks vir fyner besonderhede nagegaan kan word. Maar ook vir 'n groeiende getal gelowiges wat as ernstige Bybellesers getipeer kan word, behoort dit 'n nuwe Bybelleeservaring te open.

*Referaat gelewer by die Vertalerskongres te Hammanskraal, gereël deur die Departement Nuwe Testament, Universiteit van Pretoria, 23-25 Februarie 1999. Dit is vir hierdie publikasie uitgebrei. 
Aanvanklik het ek gedink om die teks van die 1983-Afrikaanse vertaling vir die sinopsis te gebruik. Maar dit het gou geblyk nie vir doeleindes van sinopsissamestelling geskik te wees nie ${ }^{6}$. En die 1933/1953-vertaling, hoewel meer geskik as die 1983-Vertaling, het ook nie aan die vereistes voldoen nie 7 . Die enigste uitweg was om 'n eie vertaling te maak.

\section{UITGANGSPUNT}

As uitgangspunt is aanvaar dat die vertaling die sinoptiese vergelyking moet dien. Daarmee word bedoel: die leser moet in Afrikaans met dieselfde sinoptiese data gekonfronteer word as wanneer hy/sy die Griekse teks sou lees. Om aan hierdie uitgangspunt reg te laat geskied, is daar net een uitweg: 'n letterlike vertaling - ook konkordante, formeel ekwivalente of idiolektiese vertaling8 genoem - moet gemaak word.

Die vraag is egter: wat is 'n letterlike vertaling? 'n Mens moet ver soek na 'n vertaalteorie vir letterlike vertaling'. Die redes is voor-diehandliggend: (a) teoretici vind dit nie nodig om die teorie grondliggend aan letterlike vertaling uit te spel nie, aangesien dit as redelik vanselfsprekend beskou word, en (b), vanweë die ontwikkeling van die semantiek en gepaardgaande opkoms en verfyning van dinamies-ekwivalente ${ }^{10}$ vertaalteorieë, is niemand meer in letterlike vertalings geïnteresseerd nie. Daar is finaal afskeid daarvan geneem. Trouens, vanuit dinamies-ekwivalente vertaalteorieë sou letterlike vertaling selfs as 'n ongeldige vorm van vertaling beskou kon word, veral as so 'n vertaling voorgee om neutraal te wees - dat dit nie interpretasiekeuses maak nie, maar sogenaamd getrou bly aan die grondteks. By implikasie word enige ander vorm van vertaling dan onder verdenking geplaas as sou dit eerder kommentaar as vertaling wees. Indien letterlike vertaling vandag nog vanuit hierdie of ander ideologiese ${ }^{11}$ oogmerke gedryf word, moet dit inderdaad as ongeldig aangemerk word. Geen vertaling - ook nie die letterlike nie - is vry van interpretasiekeuses nie, gewoon omdat geen twee tale semanties en struktureel volledig saamval nie, en ook omdat ons, wat die antieke tale betref, nie altyd oor genoeg agtergrondkennis beskik om in alle gevalle die brontaal presies weer te gee nie.

Bogenoemde oorwegings laat my egter steeds sonder 'n vertaalteorie vir letterlike vertaling. Daar moes gevolglik 'n eie teorie ontwikkel word. Ek verkies egter om eerder van vertaalstrategie as vertaalteorie te praat, omdat waarmee ek besig is 'n baie pragmatiese oogmerk het. Dit is 'n strategie met slegs een doel voor oë: om die leser in Afrikááns 'n venster op die sinoptiese data te bied met die oog op betekenisvolle vergelyking, 
asof die leser met die Griekse grondteks werk. Vanuit hierdie strategie is ek selfs huiwerig om van die resultaat as 'n vertaling te praat. Waarskynlik is dit meer korrek om dit "grondteksontsluiting met die oog op sinoptiese vergelyking" te noem, of, as mens die woord "vertaling" wil behou, om van 'n "werksvertaling" 12 te praat. Dit dien hom dus nie primêr as vertaling aan om as sodanig met ander vertalings op gelyke voet mee te ding nie. Maar aan die ander kant wil dit ook nie bloot 'n soort interliniêr'3 wees nie. Dit moet as Afrikaanse weergawe van die grondteks op sy eie bene staan. Dit wil weliswaar 'n ontsluiting van die grondteks wees, ja, maar 'n ontsluiting wat naby genoeg aan die Afrikaanse idioom beweeg om selfstandig en verstaanbaar te kommunikeer. Die gebruiker moet gemaklik met die Afrikaanse teks kan omgaan, maar moet weet dat die vertaalkeuses wat uitgeoefen word die eienskappe en eienaardighede van die bronteks, Grieks, vooropstel. 'n Mens sou kon sê: dis Afrikaans wat agteroor buig om die Grieks ter wille te wees. Dit klop ongeveer met Fox se tipering van sy letterlike vertaling van die Hebreeuse teks: "So I have presented the text in English dress but with a Hebraic voice"14. Dis presies wat hierdie vertaling wil wees: die Griekse teks word 'n Afrikaanse baadjie aangetrek, maar die stem is onmiskenbaar Grieks. In ligter luim, dit herinner aan wat Isak gesê het toe hy deur Rebekka en Jakob om die bos gelei is: die hande is Esau s'n, maar die stem is Jakob s'n.

\section{STRATEGIE}

Die strategie met die oog op letterlike vertaling staan op twee bene: om so naby as moontlik aan die Griekse sintaksis en taalidioom te beweeg, en om so ver moontlik 'n bepaalde Griekse woord deurgaans met dieselfde Afrikaanse ekwivalent weer te gee ${ }^{15}$. Ek gee nou in meer besonderhede aan elkeen van hierdie aspekte aandag, beginnende by die laaste.

\subsection{Slegs één Afrikaanse ekwivalent per Griekse woord}

Eers 'n terminologiese opheldering. Ek gebruik doelbewus die term "ekwivalent" en nie "betekenis" nie. Die semantiek het ons immers geleer dat dit nie woorde is wat betekenisse het nie, maar omgekeerd, betekenisse wat woorde het ${ }^{16}$. Gevolglik kan 'n enkele betekenisveld verskillende woorde hê wat binne daardie veld optree. Omgekeerd kan 'n enkele woord in verskillende betekenisvelde diens doen. Die poging om 'n bepaalde Griekse woord deurgaans met dieselfde Afrikaanse ekwivalent weer te gee, wil dus nie voorgee dat daardie Griekse woord net een betekenis het nie ${ }^{17}$. Dit is bloot 'n - soms onsuksesvolle - poging om aan die leser via die Afrikaans 
'n beeld te gee van hoe daardie Griekse woord in die sinoptiese Evangelies figureer. Vandaar die term "ekwivalent". Hierdie vertalingsekwivalente het dus volledig 'n funksionele oogmerk. Hulle wil niks meer wees nie as draers van Griekse woorde met die oog op sinoptiese vergelyking.

Die hele oogmerk met hierdie strategie is dat die leser kan weet dat elke keer wanneer ' $n$ bepaalde Afrikaanse woord teengekom word - uitgeslote hulpwerkwoorde, voegwoorde, lidwoorde, voorsetsels en partikels dit dieselfde Griekse woord is wat daardie Afrikaanse woord onderlê; omgekeerd, elke keer wanneer 'n ánder Afrikaanse woord teengekom word, is dit 'n ander Griekse woord wat dit onderlê. Hierdie kennis is noodsaaklik vir sinoptiese vergelyking. Want so kan die leser byvoorbeeld die gebruiksfrekwensie en -verspreiding van die Griekse woord dikaiosúnē met behulp van die Afrikáánse teks nagaan, omdat dikaiosúnē deurgaans met "geregtigheid" weergegee word ${ }^{18}$. Verder, die sinoptiese vergelyking geld vir beide vertikale en horisontale vergelyking, dit wil sê, om die voorkomste van byvoorbeeld "geregtigheid" in (' $n$ ) bepaalde boek(e) (vertikaal), of op 'n bepaalde punt tussen die Evangelies (horisontaal) na te gaan.

Hierdie been van die letterlike vertalingstrategie is die mees tydrowende van die hele onderneming. Want dit behels dat voordat 'n sin vertaal kan word, eers al die voorkomste van elke Griekse werkwoord, selfstandige naamwoord, byvoeglike naamwoord en bywoord in daardie sin, in die sinoptiese Evangelies met 'n konkordansie nagegaan moet word ten einde op die mees geskikte Afrikaanse ekwivalente te besluit wat in al die kontekste as vertalingsekwivalente vir daardie Griekse woorde kan diens doen. Byvoorbeeld, indien "geregtigheid" as vertalingsekwivalent vir dikaiosúne gekies is, moet mens seker wees dat dit in al die kontekste so weergegee kan word.

Dit spreek vanself dat hierdie vertalingstrategie geforseerde taalgebruik in die teikentaal tot gevolg het ${ }^{19}$. Byvoorbeeld, om prosérchomai in al sy kontekste met dieselfde vertalingsekwivalent weer te gee, moet op 'n redelik generiese Afrikaanse woord besluit word, soos "nader kom/ gaan". Hiermee word soepelheid uiteraard ingeboet. Want waar "genader" in Matteus 8:5 'n meer idiomatiese vertaling sou wees ("Toe Hy Kapernaum binnegegaan het, het 'n hoofman-oor-honderd hom genader...”), móét "nader kom" nou gebruik word (“... het 'n hoofman-oorhonderd nader gekom na hom toe ..."). Dit het dus 'n "taalstyfheid" tot gevolg wat deur die moedertaalspreker as tweede beste ervaar word, maar nogtans nie as on-Afrikaans op die oor val nie. Ander voorbeelde: om slegs één vertalingsekwivalent vir katabaínō te vind, was "neerdaal" die 
enigste moontlikheid. In Lukas 2:51 klink dit egter geforseerd om te praat van Jesus wat saam met sy ouers "neergedaal het" (van Jerusalem terug na Nasaret). "Afgegaan" sou beter gewees het. En klíno: dit word met "(laat) sak" vertaal om orals te pas. Maar in Matteus 8:20 klink dit amper onAfrikaans om te sê: "... maar die seun van die mens het nie ('n plek) waar hy die kop kan laat sak nie". Met hierdie soort resultate moet egter vrede gemaak word, omdat die primêre oogmerk nie vertaling is nie maar sinoptiese vergelyking. Die hele prosedure behels deurgaans die handhawing van 'n fyn balans tussen die optimalisering van sinoptiese vergelyking, enersyds, en verstaanbare Afrikaans, andersyds. En dit bly 'n uiters subjektiewe oordeel om telkens te bepaal of die grens van wat die Afrikaanse leser kan tolereer, nie oorskry word nie. In die laaste instansie is die enigste kriterium die vertaler se taalaanvoeling as moedertaalspreker.

Hierdie vertalingstrategie hoef egter nie net as beperkend ervaar te word nie. Vanuit 'n ander hoek gesien, is dit ook 'n heel avontuurlike oefening. Want, dit verg soms lang soektogte in Groot Tesourus van Afrikaans ${ }^{20}$ om die regte woord te vind wat in al die kontekste sal "werk", of om alternatiewe te vind wanneer die moontlikhede begin opdroog. Byvoorbeeld, daar is verskeie Griekse woorde wat almal met "beveel" weergegee kan word, te wete epitássō, diatássō, prostássō, entéllomai, keleúó en parangéllo. Om aan die vertalingstrategie van slegs één ekwivalent per Griekse woord uitvoering te gee, moes in hierdie geval redelik wyd gesoek word om uiteindelik op die volgende ekwivalente te kon besluit, respektiewelik: gelas, opdrag gee, beveel, gebied, instruksie gee en bevel gee.

In baie gevalle gee dit nie 'n groot gesoek af om slegs een vertalingsekwivalent per Griekse woord te vind nie, maar soos te verstane is hierdie soektog dikwels vrugteloos. Dit is onmoontlik om in alle gevalle 'n enkele Griekse woord met slegs een - of selfs twee, drie - vertalingsekwivalente weer te gee. Dit word natuurlik veroorsaak deur die polisemie van woorde. Voorbeelde van woorde waar mens verplig is om meer as een ekwivalent te gebruik, is: agrós (grond, land, plaas, veld); apodídomi (betaal, gee terug, rekenskap gee, vergeld); gínomai (gebeur, wees, kom, plaasvind, word); ginōskó (beken, ken, herken, besef, weet [van]); ekbállō (uitdryf, uitgooi, uithaal, uitstuur); poiéó (bewerk, doen, handel, lewer, maak, toon); en nog baie ander.

Om die saak nog verder te kompliseer, bring die verskynsel van meerdere vertalingsekwivalente noodwendig mee dat party van hulle oorvleuel (amper soos in 'n komponensiële analise waar van die betekeniskomponente van woorde oorvleuel). Dit kan dus gebeur dat 'n sekere vertalingsekwivalent na meer as een Griekse woord verwys. Byvoorbeeld: 
"woord" kan na lógos of rēma verwys, "ken" na ginōskō of oîda, "kom" na gínomai of érchomai, "land" na agrós of gē, "noem" na kaléo of légo, "oor" na akoē of oûs, "goed" na agathós of kalós, ensovoorts. Uiteraard bring hierdie verskynsel die beginsel van één vertalingsekwivalent vir één Griekse woord in die gedrang. Daar is egter geen manier waarop dit vermy kan word nie. Letterlike vertaling volgens die onderhawige vertalingstrategie is net tot op sekere hoogte haalbaar.

Om die probleem van oorvleuelende ekwivalente enigermate die hoof te bied, word die leser met 'n sisteem van syfers op hierdie verskynsel attent gemaak. Dit werk só: in 'n addendum word die volledige Afrikaans-Griekse ${ }^{21}$ woordelys opgeneem. Die vertalingsekwivalente wat oorvleuel, word met unieke syfers gemerk. Wanneer hierdie vertalingsekwivalente in die teks voorkom, word hulle ook met dieselfde syfers in superposisie gemerk. Deur van die teks na die addendum te beweeg, kan die leser dus presies te wete kom watter Griekse woord die vertalingsekwivalent onderlê. Byvoorbeeld, by elke voorkoms van "woord" word die leser na die addendum gelei en kan hy/sy uitvind of lógos of rëma ter sprake is. Verder, in ' $\mathrm{n}$ ander addendum word ook die volledige GrieksAfrikaanse woordelys opgeneem. Dit stel die leser weer in staat om 'n algemene beeld te kry van watter vertalingsekwivalente vir al die Griekse woorde gebruik word.

Ek veroorloof myself een uitsondering in die strategie om vir elke Griekse woord slegs een vaste vertalingsekwivalent te hê, en dit is by die vertaling van Griekse voorsetsels. Hier probeer ek nie rigied met vaste Afrikaanse ekwivalente vertaal nie. Die rede is voor die handliggend: voorsetsels is uiters taalspesifieke bousels. Om hier 'n vaste patroon te probeer volg, sal tot onmoontlike segswyses in Afrikaans lei. Selfs al sou mens met vaste ekwivalente wou werk, sal die uitsonderings so akkumuleer dat die sisteem mettertyd in duie stort. Griekse voorsetsels word dus dinamies en kontekstueel vertaal. In een geval is egter 'n vaste patroon ontwikkel. Die Grieks légein pros autoús word in Afrikaans deurgaans met "sê aan hulle" weergegee (légein autoîs word weer konstant met "sê vir hulle" vertaal).

'n Ander faset van die letterlike vertalingstrategie is om woorde wat in Grieks dieselfde stam het, in Afrikaans ook met stamverwante ekwivalente te vertaal. Byvoorbeeld: agalliáo/agalliasis: bly wees/blydskap; axióo/áxios: werd ag/werd; bathúnō/báthos: diep uitgrawe/diepte; dialogízomai/dialogismós: redeneer/redenering; parthénos/parthenía: maagd/maagdskap; perisseúóperissós: oorvloedig wees/oorvloed; splanchnizomai/splánchnon: innig jammer kry/innigheid; sōzō/ 
sōtēr/sótēria: red/redder/redding; teleutáó/teleutẽ: aan die einde kom/uiteinde; hupsó/húpsos: verhoog/hoogte; ensovoorts.

Ten slotte wat hierdie deel betref, interessantheidshalwe 'n opmerking oor kúrios. Soos bekend, tref dinamies-ekwivalente vertalings 'n onderskeid tussen kúrios as aanspreekvorm vir God, of vir Jesus wanneer dit volgelinge en ander mense is wat hulle vertroue in Hom stel, enersyds, en wanneer dit nie-volgelinge is, andersyds. Byvoorbeeld, die 1983Afrikaanse Vertaling vertaal met "Here" in eersgenoemde gevalle en "meneer" in laasgenoemdes. In my vertaling word egter geen onderskeid getref nie; daar word deurgaans met "Heer" vertaal. Daar is twee oorwegings vir dié vertalingskeuse: eerstens word voldoen aan die ideaal van slegs een vertalingsekwivalent per Griekse woord, en tweedens is "Heer" 'n neutraler woord as "Here" 22, maar tog in 'n hoër register as "meneer". Dit bring mee dat "Heer" as aanspreekvorm vir Jesus en God kan diens doen, maar terselfdertyd ook vir mense gebruik kan word. (Vir die kwessie van "Heer" as hoofletter of nie, kyk 3.2.14.)

Moeiliker is die besluit rondom die hoflikheidsaanspreekvorm vir Jesus en ander hoogwaardigheidsbekleërs. Moet mens deurgaans met "jy" vertaal, omdat die brontaal nie onderskei tussen " $u$ " en "jy" nie? Uiteraard val dit nie goed op die Afrikaanse oor nie, maar dis ten minste konsekwent volgens die letterlike vertalingstrategie. Dit het ook die verdere voordeel dat die leser op dié manier daarop attent gemaak word dat die brontaal nie hierdie onderskeid ken nie. Op die oomblik vertaal ek deurgaans met "jy”, maar die klompie gevalle waar "Heer" en "jy" in dieselfde asem as aanspreekvorm voorkom, val vreemd op die Afrikaanse oor - vergelyk Matteus 8:2: "Heer, as jy wil kan jy my reinig". 'n Finale beslissing is dus nog hangende.

Vervolgens die tweede been van die letterlike vertalingstrategie.

\subsection{Naby beweeg aan die Griekse sintaksis en taalidioom}

Dit moet weer beklemtoon word dat die strategie om so na as moontlik aan die Griekse sintaksis en taalidioom te beweeg, nie met een of ander ideologiese uitgangspunt omtrent vertaling verbind moet word nie, maar 'n funksionele oogmerk het. Dit wil naamlik die sinoptiese vergelyking dien. Wanneer die Sinoptici met mekaar vergelyk word, is dit belangrik dat die leser via die Afrikaans ook 'n kykie kry in die sintaktiese ooreenkomste en afwykings tussen die sinoptiese Evangelies.

Die naby beweeg aan die Griekse sintaksis en taalidioom behels die volgende: 
3.2.1 Daar word so streng moontlik gehou by die Griekse woordorde. Wanneer sinoptiese parallelle afwesig is (soos by die Sondergut), kan ietwat vryer vertaal word, omdat die funksionele dringendheid van woordorde-vergelyking dan ontbreek. Maar wanneer daar met parallelle materiaal gewerk word, is dit vanuit die gesigpunt van vertaling met die oog op sinoptiese vergelyking belangrik om by die Griekse woordorde te hou. Uiteraard het dit soms geforseerde vertaling tot gevolg23, maar die sinoptiese vergelyking geniet voorrang. Uit onderstaande voorbeeld blyk duidelik dat daar in die onderstreepte gedeelte 'n woordorde-verskil tussen Matteus en Lukas is. Dit het nie enige betekenisverskil nie, maar dit bring nogtans onder die leser se aandag dat hoewel beide vertalings se woordordes vir die Afrikaanse oor geforseerd voorkom, albei in die Grieks aanvaarbare sintaksis is.

Matteus 6:27

Wie uit julle, deur hom te bekommer, kan toevoeg tot sy grootte een el?
Markus

Wie uit julle, deur hom te bekommer, kan tot sy grootte toevoeg 'n el?

Navolging van die Griekse woordorde veroorsaak dikwels ook vreemde sintaksis vir die Afrikaanse taalgevoel op frase-vlak. Byvoorbeeld: "En nadergegaan het hy haar opgerig nadat hy die hand gegryp het ..." (Mark 1:30). Die onderstreepte frase sal normaalweg in Afrikaans vroeër in die sin staan, soos (ietwat meer idiomaties vertaal): "En hy het nadergegaan, haar hand gegryp en haar opgerig".

In die geval van sekere genitiefverbindings word die woordorde egter nie letterlik nagevolg nie. Die bekende Griekse sintaksis om besit of relasie uit te druk deur middel van die persoonlike voornaamwoord in plaas van die besitlike voornaamwoord, byvoorbeeld: ho patēr hēmōn, word nie met: "die Vader van ons" vertaal nie, maar deurgaans met: "ons Vader".

3.2.2 Daar word gepoog om so na as moontlik aan die aantal Griekse woorde van die grondteks te bly. Dit behels twee aspekte. Enersyds, nie minder woorde as die Grieks nie. Dit hou in dat elke Griekse woord van 'n vertalingsekwivalent voorsien word, amper soos in 'n interliniêr. Partikels, soos mén, dé, án en gé, word egter merendeels onvertaald gelaat, behalwe waar hulle beduidend betekenisdraend is. Byvoorbeeld (dé onvertaald): "Iemand het vir hom gesê (Eîpen dé tis autō): "Heer, is dié wat gered word min?" Hy het aan hulle gesê (ho de eîpen pròs autoús): “... (Luk 
13:23). Dé wel vertaal: “Ék egter (dé) sê vir julle “... (Mat 5:22); Jý egter (dé), wanneer jy bid, gaan in jou binnekamer in ..." (Mat 6:6); "maar (dé) hy ... het weggegaan" (Luk 4:30). Dis gewoonlik in gevalle waar dé kontras uitdruk dat dit vertaal word.

Andersyds is die ideaal: nie méér woorde as die Grieks nie. Vanweë die groot verskille in taalstruktuur tussen Afrikaans en Grieks is so 'n ideaal egter nie naastenby haalbaar nie. Grieks beskik oor die vermoë om 'n saak baie kernagtiger te stel as Afrikaans - of enige moderne taal, wat dit betref. Afrikaans het gewoon meer woorde nodig om dieselfde te sê as wat die Grieks kort kan sê. Dis veral waar by die Griekse werkwoord, want afgesien van die feit dat laasgenoemde dikwels ingeboude betekenisnuanses bevat wat slegs met meerdere Afrikaanse woorde weergegee kan word (vir voorbeelde kyk volgende paragraaf), het dit ingebedde persoonsaanduidings en benodig dit meermale hulpwerkwoorde in Afrikaans. Dieselfde geld ook die naamvalle van die Griekse selfstandige en byvoeglike naamwoord - ook hier word meerdere Afrikaanse woorde vereis. Dus, die ideaal van nie méér woorde as die Grieks nie beteken in die praktyk dat na woordekonomie gestreef word, dit wil sê, nie meer woorde as wat nodig is nie.

Wanneer 'n Griekse (werk)woord noodwendig met meer Afrikaanse woorde weergegee moet word, word die vertalingswoorde met koppeltekens verbind ten einde die leser daarop attent te maak dat dit in die Grieks één woord is. Byvoorbeeld: anáblepsis: herstel-van-sig; anairéo: om-die-lewe-bring; atenizō: stip-aankyk; douleúō: dien-soos-'n-slaaf; euangelizomai: blye-boodskap-bring; ensovoorts. Maar, die samestellende dele van die Afrikaanse werkwoordformasie wat nie inherent deel van die vertalingsekwivalent is nie, word nie van koppeltekens voorsien nie, byvoorbeeld: "hy het instruksie-gegee" (ekéleusen) (Mat 8:18). "Instruksie-gee" is die vertalingsekwivalent wat uit twee Afrikaanse woorde bestaan, daarom die koppelteken; "hy het" is egter nie inherent deel van die vertalingsekwivalent nie, maar vorm die persoons- en tydsaanduiding van die Griekse werkwoord, daarom geen koppelteken in Afrikaans nie. (Die "ge" van "gegee" is natuurlik ook deel van die tydsaanduiding, maar moet onvermydelik vas aan "gee" geskryf word.)

3.2.3 Partisipia is ' $n$ volgende interessante fenomeen wat besondere eise aan letterlike vertaling stel. Anders as byvoorbeeld Engels, maak Afrikaans nie meer oorvloedig van partisipia gebruik nie, behalwe in relatief vaste uitdrukkings soos "gedeelde belange" of: "hulle marsjeer al singende". In baie gevalle is dit dus nie moontlik om Griekse partisipia met 
Afrikaanse eweknieë weer te gee nie. Byvoorbeeld: “En nadat die demoon hom neergegooi het in die middel het hy uitgegaan van hom" (Luk 4:35). (Ripsan autòn to daimónion kan beswaarlik in Afrikaans vertaal word met: "Die duiwel hom neergegooi..."); "Elkeen wat na my toe kom en wat my woorde hoor en wat hulle doen..." (Luk 6:47). ('n Mens sou beswaarlik kon vertaal: "Elke komende na my toe en horende my woorde en hulle doenende ..."). Tog word uitgegaan van die standpunt dat waar enigsins moontlik, partisipia ook in Afrikaans gebruik sal word, selfs al lei dit tot ietwat geforseerde uitdrukkings. Die vertalingstrategie wat aanvaar is, wil immers die leser met die Griekse taalidioom konfronteer. Daarom sal die volgende soort vertalings dikwels teëgekom word: "En hy het rondgegaan in die hele Galilea al lerende ... al verkondigende ... en al genesende ..." (Mat 4:23); “... en geopen sy mond het hy hulle geleer seggende ... (Mat 5:2); "En uitgesteek die hand het hy hom aangeraak ..." (Mat 8:3); "En hy sê vir hom: 'Ek, gegaan, sal hom genees'” (Mat 8:7).

Die gebruik van partisipia het die verdere voordeel dat dubbelsinnighede in die Grieks in die vertaling so gelaat kan word. Dikwels is daar onsekerheid of mens met, 'n temporele of toegewende bysin te doen het. Byvoorbeeld, moet die partisipiale bysin in Lukas 5:5 temporeel vertaal word: "Meester, nadat ons deur die hele nag hard gewerk het het ons niks gekry nie", of toegewend: "... hoewel ons deur die hele nag hard gewerk het ...? Daarom word vertaal: "Meester, deur die hele nag hard gewerk ...". Die vertaling met 'n partisipium probeer dus nie die onsekerheid opklaar nie. Dit kan die leser wat nie met Grieks bekend is nie, help verstaan waarom vertalings so verskil in interpretasie.

Die voorbeeld in Matteus 8:7 hierbo illustreer ook 'n ander interessantheid van partisipia, spesifiek van die participium conjunctum ${ }^{24}$ van (ap)érchomai. Streng grammatikaal gesien, moet die verlede deelwoord "gegaan" in Matteus 8:7 as 'n voorafgaande handeling voor "sal hom genees" verstaan word. In Afrikaans sal dié twee egter as één of gelyktydige handeling uitgedruk word: "Ek sal gaan en hom genees", of: "Ek sal hom gaan genees". In 'n letterlike vertalingstrategie word die verlede deelwoord egter grammatikaal genuanseerd vertaal om aan die leser dié Griekse taaleienaardigheid tuis te bring. Nog voorbeelde: “Weggegaan, wys jouself vir die priester (Luk 5:14 = "Gaan wys jouself ..."); "[Heer], gee-toestemming aan my om eers, weggegaan, my vader te begrawe" (Luk 9:59 = Heer, laat my toe om eers my vader te gaan begrawe"); “... maar jý, gegaan, dra die koninkryk van God uit" (Luk 9:60 = "maar gaan dra jý die koninkryk van God uit"). 
3.2.4 Nominale sinne word waar moontlik so gelaat, byvoorbeeld: "Salig die armes van gees, want hulle s'n is die koninkryk van die hemele" (Mat $5: 3) ;$ "... hoe nou die poort en smal die pad wat weglei na die lewe" (Mat 7:14). Wanneer daar egter twyfel is oor die goeie segswyse in Afrikaans, word werkwoorde voorsien, byvoorbeeld: "Gaan in deur die nou poort; want wyd (is) die poort en breed (is) die pad wat weglei na die verderf ..." (Mat 7:13); “... laat toe dat ek die splinter uit jou oog uithaal, en kyk die balk (is) in jou oog?" (Mat 7:4). Die ronde hakies dui vir die leser aan dat "is" nie in die grondteks voorkom nie (kyk verder hieroor by 3.2.12).

3.2.5 Griekse idiome en ander segswyses eie aan die Grieks veroorsaak unieke probleme vir 'n letterlike vertaling. As vóórsetsels uiters taalspesifiek is, soveel te meer idiome en ander soortgelyke uitdrukkings. 'n Dubbele strategie word in dié gevalle gevolg. (a) Waar 'n segswyse wel vreemd op die Afrikaanse oor val, maar nogtans verstaanbaar is, word dit letterlik vertaal sonder enige verdere verduideliking. Byvoorbeeld: "... en vir hom was daar 'n vrou uit die dogters van Aäron ..." (Luk 1:5). Die onderstreepte deel, wat 'n standaarduitdrukking in Grieks is, sal in idiomatiese Afrikaans eerder so klink: “... en hy het 'n vrou gehad uit die dogters van Aäron ...". Maar omdat die letterlike weergawe tog nie onverstaanbaar is nie, word dit so gelaat. (b) In gevalle waar die oorspronklike heel vreemd is, word dit eers letterlik vertaal en onderstreep, en dan tussen gekrulde hakies en in ' $n$ ander lettertipe met idiomatiese Afrikaans weergegee. Byvoorbeeld: “... en albei wat gevorderd was in hulle dae $\{=$ jare\}" (Luk 1:7); "En kyk jy sal ontvang in die maag $\{=$ swanger word $\}$ en 'n seun baar" (Luk 1:31); "En daar was herders in dieselfde gebied wat buite in die veld was en wat bewaar het die wake van die nag oor hulle kudde $\{=$ in die nag wag gehou het oor hulle kudde $\}$ " (Luk 2:8); “... en hulle het 'n groot vrees gevrees $\{=$ was baie bang\}" (Luk 2:9); “... hierdie (vrou) wat gevorderd was in baie dae $\{=$ jare $\}$, wat geleef het met (haar) man sewe jaar vanaf haar maagdskap $\{=$ voorheen slegs sewe jaar getroud was\}" (Luk 2:36); "Dit is gesê: wie sy vrou losmaak $\{=$ skei\}, moet haar 'n skeibrief gee" (Mat 5:31); "En as julle liefhet dié wat (vir) julle liefhet, watter soort genade is dit vir julle? $\{=$ meriete hou dit vir julle in?\}" (Luk 6:32); “... en hy het geskreeu seggende: 'Wat vir ons en vir jou, Jesus Nasarener?' $\{=$ wat het ons met jou te doen\}" (Mark $1: 24)$.

3.2.6 So ver moontlik word ook gepoog om aan die woordsoorte reg te laat geskied. Griekse wérkwoorde word dus met Afrikaanse wérkwoorde, 
selfstandige naamwoorde met selfstandige naamwoorde, ensovoorts, weergegee. 'n Voorbeeld sal verduidelik: in Lukas 2:14 sou 'n mens die frase en anthröpois eudokías kon weergee met: "... onder mense in wie hy 'n welbehae het". Dit maak van eudokía egter 'n werkwoord. Daarom word vertaal: "onder mense van (sy) welbehae".

3.2.7 'n Sensitiwiteit word geopenbaar vir die aktiewe of passiewe vorm van die werkwoord - aktiewe werkwoorde word aktief en passiewe werkwoorde passief vertaal. In Lukas 3:23 sou mens die uitdrukking hös enomizeto in meer idiomatiese Afrikaans kon vertaal met: “... soos hulle gedink het ...”. Enomizeto is egter passief. Daarom word vertaal: "soos dit gedink is".

3.2.8 Daar word nie probeer om die onderskeid tussen die Griekse werkwoord "tye", byvoorbeeld imperfektum, aoristus en perfektum, in die vertaling weer te gee nie. In bepaalde gevalle sou dit wel moontlik wees, veral by die perfektum, maar omdat hierdie onderskeid in die meeste gevalle in die Afrikaans óf verlore gaan of onmoontlik is om weer te gee, word dit daar gelaat. In elk geval vind Griekse taalkundiges dit moeilik om die presiese aard van die nuanseverskille tussen die Griekse werkwoordtye te beskryf.

3.2.9 Iets wat nogal verwarring kan veroorsaak, is die manier waarop persoonlike voornaamwoorde in die Griekse teks gebruik word. In dinamiese vertalings word hierdie verwarring gewoonlik "uitgesuiwer". In 'n letterlike vertaling kan dit egter nie gebeur nie. Daarom kom daar dikwels iets soos die volgende voor: "Maar uitgegaan het hy begin om baie te verkondig en die woord alom-bekend-te-maak, met die gevolg dat hy nie meer openlik in 'n stad kon ingaan nie, maar buite op verlate plekke was; en hulle het van oraloor na hom toe gekom" (Mark 1:45). Dis nie meteens duidelik nie, maar die eerste hy verwys na die melaatse, die tweede $h y$ - en hom - na Jesus, terwyl hulle die skare aandui. Die verband bring wel duidelikheid, maar eers nadat mens twee keer gedink het. So kan die leser ook te wete kom met watter probleme vertalers te kampe het.

3.2.10 Wat die bepaalde lidwoord betref, laat ek my lei deur die grondteks, maar soms is dit nodig om ter wille van die Afrikaanse idioom aanpassings te maak, dit wil sê, lidwoorde weg te laat of by te voeg. Byvoorbeeld, in Matteus 6:25 kom "voedsel” en "klere" mét lidwoorde in die grondteks voor. In die vertaling laat ek hulle egter weg, want dis on- 
Afrikaans om hier te vertaal: "Is die lewe nie meer as die voedsel en die liggaam as die klere nie?" Omgekeerd: soms word 'n lidwoord bygevoeg ter wille van die Afrikaanse idioom, byvoorbeeld: “... sodat (jy) nie ... in die tronk gegooi word nie” (Mat 5:25); “die Heilige Gees ...” (Luk 1:35).

3.2.11 Ter wille van die sinoptiese vergelyking moet die teks in kolomme geplaas word. Dit het tot gevolg dat die sinne soms op vreemde plekke afgebreek word. Gebrek aan ruimte plaas ook beperkinge op die lengte van frases. Nogtans word so ver moontlik gepoog om die teks in sinvolle semotaktiese eenhede te verdeel (kyk voorbeeld aan die einde).

3.2.12 Die volgende tegnieke word aangewend om bepaalde bewerkings van die teks voor te stel. Ronde hakies (...) word gebruik om woorde wat nie in die oorspronklike voorkom nie, maar ter wille van die groter verstaanbaarheid in Afrikaans bygevoeg moet word, aan te dui. Byvoorbeeld: "... wie (die gebooie) egter doen en leer, hierdie een sal groot genoem word ..." (Mat 5:19); "Die jakkalse het lêplekke ... maar die seun van die mens het nie ('n plek) waar hy die kop kan laat sak nie" (Mat 8:20). Vierkantige hakies [...] het dieselfde funksie as in die Nestle-Aland Griekse teks, naamlik om woorde wat tekskrities onseker is, aan te dui. Byvoorbeeld: “... wanneer hulle julle beledig ... [terwyl hulle valslik praat] ter wille van my" (Mat 5:11). Puntige hakies $\langle\ldots\rangle$ word gebruik om woorde wat wel in die grondteks staan, maar wat probleme vir die vertaling oplewer, weer te gee, byvoorbeeld: "En dit het vervolgens gebeur <en> hy het deurgereis na elke stad en dorp ..." (Luk 8:1).

3.2.13 Die punktuasie van die gebruikte Griekse teks (Nestle-Aland27) word deurgaans gevolg: punte word met punte weergegee, kommas met kommas, die verhewe punt met 'n kommapunt, en kommapunte met vraagtekens. Uiteraard het die besluit om die Griekse punktuasie te volg soms vreemde sinsverdelings tot gevolg. Waar Afrikaans 'n punt sou hê, staan nou dikwels net 'n kommapunt, byvoorbeeld: “... nóg bring hulle bymekaar in skure, en julle hemelse Vader voed hulle; is julle nie meer waardevol as hulle nie?" (Mat 6:26).

In bepaalde gevalle word die grondteks se punktuasie egter aangepas. (a) By direkte rede: hier word aanhalingstekens bygevoeg ter wille van groter leesbaarheid in die teikentaal. (b) In sommige gevalle word kommas ingevoeg ter wille van groter duidelikheid, byvoorbeeld: “... 'n goeie maat, ingedruk, geskud, wat oorloop, sal hulle in julle boesem gee" (Luk 6:38). (c) Af en toe word ook van aandagstrepe gebruik gemaak, 
byvoorbeeld: "Sodat julle kan sien dat die seun van die mens gesag het om op aarde sondes te vergewe -" sê hy toe vir die lamme: "opgerig, tel-op jou bed en gaan na jou huis" (Mat 9:6).

\subsubsection{Die hoofletter-/kleinletterkonvensie van die Nestle-Alandteks word} by die Afrikaanse sisteem aangepas. Nuwe sinne word dus met hoofletters begin. (Die grondteks het slegs aan die begin van nuwe paragrawe - en by eiename - hoofletters). Verder, hoewel die grondteks kleinletters het by theós, kúrios, en patēr, word hierdie woorde deurgaans met beginhoofletters weergegee, aangesien/wanneer hulle na God of Jesus verwys. Benamings vir God, soos Almagtige, Allerhoogste en Redder, word met begin-hoofletters geskryf. Benamings vir Jesus, soos "heilige" en "seun van die mens", word egter met kleinletters gelaat. Wanneer pneûma of hágion na die Heilige Gees verwys, word dit met hoofletters geskryf.

\section{VOORBEELD}

Die Engelse spreekwoord lui: "the proof of the pudding lies in the eating". Daarom gee ek ten slotte 'n kort uittreksel uit die sinopsis om 'n kykie te gee in die vertaling en uitleg van die sinopsis.

\section{Genesing van 'n melaatse}

\section{Mt 8:2-4}

2 En kyk

'n melaatse, nadergekom,

het voor hom neergekniel

seggende:

"Heer,

3 En

as jy wil kan jy my reinig."

uitgesteek die hand het hy hom aangeraak seggende:

"ek wil, word gereinig," en dadelik

is sy melaatsheid

gereinig.

4 En Jesus sê vir hom:

"sien (toe) dat

jy vir niemand sê nie, maar
MK $1: 40-45$

40 En

daar kom 'n melaatse na hom toe wat hom smeek

[en wat neerval-op-sy-kniee]]

en wat vir hom sê:

“as jy wil kan jy my reinig."

41 En innig-jammer-gekry, uitgesteek die hand het hy hom aangeraak en hy sê vir hom:

"ek wil, word gereinig;"

42 en dadelik

het weggegaan van hom

die melaatsheid,

en hy is gereinig.

43 En nadat hy hom hard-aangespreek het het hy hom dadelik uitgestur.

44 En hy sê vir hom: "sien (toe) dat jy vir niemand iets sê nie, masr
Lk 5:12-16

12 En dit het gebeur toe hy in een van die stede was kyk (daar was)

'n man vol van melaatsheid;

Jesus gesien, geval op die aangesig het hy by hom gepleit seggende:

"Heer,

13 En

as jy wil kan jy my reinig."

uitgesteek die hand het hy hom aangeraak seggende:

"ek wil, word gereinig;"

en dadelik

het

die melaatsheid

weggegaan van hom.

14 En hy

het bevel-gegee aan hom

om vir niemand te sê nie, maar. 
gaan

wys jouself vir die priester

en bring

die gawe wat Moses beveel hes, tot getuienis vir hulle."

\begin{abstract}
gaan
wys jouself vir die priester

en bring

aangaande jou reiniging

wat Moses beveel het,

tot getuienis vir hulle."
\end{abstract}

45 Maar uitgegaan

het hy begin om baie te verkondig

en die woord

alom-bekend-te-maak,

met die gevolg dat hy nie meer

openlik in $\mathrm{n}$ stad kon ingaan nie, maar

buite op verlate plekke was;

en hulle het van oraloor

na hom toe gekom. "weggegaan

wys jouself vir die priester

en bring

aangaande jou reiniging

soos Moses beveel het,

tot getuienis vir hulle."

15 Maar

die woord oor hom

het nog meer deurgegaan,

en baie skares het saamgekom

om te hoor en genees te word

van hulle krankhede.

16 Maar hy was terugtrekkende in verlate (plekke)

en biddende.

\section{NOTAS:}

1 Die mees gebruiktes is dié van $\mathrm{K}$ Aland, Synopsis quattuor evangeliorum, Stuttgart ${ }^{13} 1985$; A Huck \& $\mathrm{H}$ Greeven, Synopse der drei ersten Evangelien/Synopsis of the first three Gospels, Tübingen 131981; en M-É Boismard \& A Lamouille, Synopsis Graeca quattuor evangelionum, Leuven 1986.

2 Byvoorbeeld H F D Sparks, A synopsis of the Gospels. Part I: The synoptic Gospels with the Johannine parallels, London 1970; B H Throckmorton (ed), Gospel parallels: A synopsis of the first three Gospels, with alternative readings from the manuscripts and noncanonical parallels, New York 21957; J B Orchard, A synopsis of the four Gospels in a new translation, Macon 1982; R W Funk, New Gospel parallels. Vol 1: The synoptic Gospels. Vol 2: John and the other Gospels, Philadelphia 1985; R W Funk, New Gospel parallels. I/2: The Gospel of Mark, Sonoma 1990.

3 J Schmid, Synopse der drei ersten Evangelien. Mit Beifügung der JohannesParallelen, Regensburg 61971; R Pesch (\& U Wilckens \& R Kratz), Synoptisches Arbeitsbuch zu den Evangelien, 5 Vols, Köln 1980-81.

4 L Deiss, Synopse de Matthieu, Marc, et Luc avec les paralleles de Jean. 2. Textes, Parys ${ }^{31976 ;}$ P Benoit \& M-É Boismard, Synopse des quatre évangiles en français avec parallèles des apocryphes et des Pères, Parys 21973.

$5 \quad$ J Keulers, Synopsis van de eerste drie evangelien, Maaseik 1958; A Denaux \& M Vervenne, Synopsis van de eerste drie evangeliën, Leuven 1986.

6 Die dinamies-ekwivalente vertalingsteorie wat gevolg is, bemoeilik sinoptiese vergelyking. 
7 Hoewel hierdie vertaling meer letterlik as die 1983-Vertaling is, is dit steeds nie letterlik genoeg nie. Wat ook teen hom tel, is die feit dat dit nog op die Textus Receptus berus, en ook dat hierdie vertaling vir baie Afrikaanssprekendes nie meer nie, of al minder, in die volksmond leef.

8 Vergelyk Denaux \& Vervenne, $a w$, XVI-XVII.

9 Die naaste wat ek hieraan kon kom, is te vinde in Fox se letterlike vertaling van die Pentateug, die sogenaamde Shocken Bible (E Fox, The Five Books of Moses, New York, Schocken Books, 1995, xviii). In die voorwoord verduidelik Fox die teorie waarop sy vertaling berus. Dit behels kortliks: die teks word in kola gestruktureer, transliterasie en verduideliking van Hebreeuse name, aandag vir sleutelwoorde, woordspel, toespelings en repetisie. Hierdie teorie, wat op sy beurt teruggryp op dié van die Duitse vertaling van Buber \& Rosenzweig (19251962), is egter gemik op die mondelinge/oudiologiese aard van die Hebreeuse Bybel. As sodanig is dit nie bruikbaar vir my doeleindes nie, hoewel enkele detailaspekte ooreenstem.

10 Sedert die verskyning van J de Waard \& E A Nida se boek in 1986, From one language to another, word daar eerder van "funksioneel-ekwivalente" vertaalteorie gepraat. Vergelyk E R Hope, "Redefining a functional theory of translation", Current trends in Scripture translation, UBS Bulletin 182/183 (1997), 7-19; en K F de Blois, "Functional equivalence in the nineties", $a w$, 21-29.

11 Soos byvoorbeeld vanuit 'n grafiese inspirasieteorie waarvolgens letterlik elke woord van die brontaal geïnspireerd is en daarom in die vertaling behoue moet bly.

12 Vergelyk Denaux \& Vervenne, $a w$, XVII.

13 E A Nida, Toward a science of translating, Leiden 1964, 23, noem die interliniêr die mees letterlike vorm van vertaling.

14 Vergelyk Fox, $a w$, ix.

15 Vir 'n soortgelyke werkwyse, kyk M Buber, "A translation of the Bible", in: M Buber \& F Rosenzweig, Scripture and translation (transl. L Rosenwald with E Fox), Indianapolis, 1994 [1927], 167.

16 Vergelyk J P Louw, Semantiek van Nuwe-Testamentiese Grieks, Pretoria 1976, 75.

17 Vergelyk J Botha, Semeion, Pretoria 1990, 125-126, vir 'n verduideliking van die verskil tussen betekenis en vertaalekwivalent.

18 Dit stem ongeveer ooreen met Buber se nosie van Leitwörter - vergelyk L Rosenwald, "Buber and Rosenzweig's challenge to translation theory", in: Scripture and translation, xxxix. Volgens die Leitwort-beginsel moet sekere brontaalwoorde konsekwent met dieselfde vertalingsekwivalente vertaal word sodat die brontaal se patrone ook in die teikentaal sigbaar kan word.

19 Vergelyk Fox, $a w, 1995$, xix, vir 'n soortgelyke opmerking.

$20 \quad$ L G de Stadler, Halfweghuis 1994.

21 Alle Griekse woorde word ter wille van wyer gebruik getranskribeer.

22 Dis interessant dat Afrikaans, in navolging van die Nederlands, 'n meervoudsvorm - "Here" - gebruik om na Jahwe en Jesus (lg in bepaalde gevalle) te verwys (vgl ook die Hebreeuse meervoud 'elohim vir die benaming "God"). Hierdie gebruik is waarskynlik gevestig uit eerbied vir die Godsnaam 
“Jahwe", 'n tradisie wat ver in die vertalersgeskiedenis teruggaan. Vir 'n oorsig oor die vertaling van die Godsnaam in antieke en meer moderne vertalings, kyk J P Oberholzer, "Die weergawe van die Godsnaam met 'Here' in die Nuwe Afrikaanse Bybelvertaling", in: W S Prinsloo en W Vosloo, In mensetaal oor God se Woord (FS vir A H van Zyl), Kaapstad 1988, 97-104.

23 E A Nida, $a w$, 2, sê dat die vertaler voortdurend vasgevang is in die konflik tussen vorm en inhoud. Probeer hy so na as moontlik aan die vorm hou (bv woordorde), gaan daar inhoudelike betekenis verlore; hou hy hom weer streng aan betekenis, gaan daar baie van die oorspronklike styl verlore.

24 Vergelyk F Blass, A Debrunner \& F Rehkopf, Grammatik des neutestamentlichen Griechisch, Göttingen 1979, §418(5b); H E Dana \& J R Mantey, A manual grammar of the Greek New Testament, Toronto 1957, 228-229 (circumstantial participle). 